\title{
Segmentation and Positioning of Lecturers in the Department of Computer Science at Pakuan University Based on Student Assessment ${ }^{*}$
}

\author{
Segmentasi dan Positioning Dosen Jurusan IImu Komputer \\ Universitas Pakuan Berdasarkan Penialian Mahasiswa
}

\author{
Yusma Yanti ${ }^{1 \ddagger}$ and Asep Saepulrohman² \\ 1,2Jurusan Ilmu Komputer Universitas Pakuan, Indonesia \\ ${ }^{\ddagger}$ corresponding author: yusmayanti.fn@gmail.com
}

Copyright ( 2021 Yusma Yanti and Asep Saepulrohman. This is an open-access article distributed under the Creative Commons Attribution License, which permits unrestricted use, distribution, and reproduction in any medium, provided the original work is properly cited.

\begin{abstract}
Determining the segmentation and positioning of the lecturers in selecting the thesis supervisor is very important to do. It is because, with this information, the supervision process in thesis writing can run well. This study intends to analyze the segmentation and positioning of lecturers related to determine the thesis supervisor using the Clusterwise Bilinear Spatial Multidimensional Scaling Model (CBSMSM) method. The data used is survey data for fifth-semester bachelor students of the 2019/2020 academic year of the Department of Computer Science, Pakuan University. One hundred sixtyone student observations provide an assessment of 10 attributes regarding the characteristics of 32 lecturers of the department. Furthermore, the estimation of the segment coordinate parameters, lecturer coordinates, dimensions, and attributes simultaneously uses the alternating least square (ALS) algorithm. The number of segments and dimensions are selected based on the smallest sum square error (SSE) value for combining segments and other dimensions. As a result, we get four segments and four dimensions with an SSE value of 4864.003. Furthermore, the department can use this result to illustrate student assessments of their lecturers' characteristics regarding thesis supervision.
\end{abstract}

Keywords: Clustering, Least Square Algorithm, Positioning, Segmentation, Student Thesis

\footnotetext{
* Received: Nov 2020; Reviewed: Mar 2021; Published: Mar 2021
} 


\section{Pendahuluan}

Jurusan Ilmu Komputer Universitas Pakuan memiliki visi menjadikan program studi (Prodi) yang unggul, mandiri dan berkarakter pada sistem otomasi dan aplikasi cerdas berbasis komputer. Prodi ini memiliki empat kelompok keilmuan yaitu, Computer Science, multimedia, hardware dan sistem informasi. Dalam perkembangannya, Prodi Ilmu Komputer Universitas Pakuan meroket dengan sangat pesat. Jumlah mahasiswa baru untuk setiap angkatan mencapai rata-rata 300 mahasiswa. Fasilitas secara bertahap juga ditingkatkan menuju lebih baik. Tak terlupa juga kualitas tim dosen yang berkualitas baik dan saling berkesinambungan. Namun, rasio antara jumlah dosen dengan jumlah mahasiswa hingga saat ini belum dapat dikatakan ideal. Permasalahan ini terlihat sederhana, namun kenyataannya sangat berdampak pada kualitas lulusan dan akreditasi prodi dimasa yang akan datang. Ketidakidealan rasio jumlah mahasiswa dengan jumlah dosen salah satunya berpengaruh disaat penyusunan skripsi/ tugas akhir mahasiswa. Terkadang, mahasiswa tidak bisa mendapatkan bimbingan secara maksimal. Kesesuaian antara bidang keilmuan dosen pembimbing skripsi dengan mahasiswa bimbingan merupakan salah satu faktor pendukung dalam mempercepat masa studi. Sehingga dengan adanya kesesuaian ini, dapat menekan angka kelulusan mahasiswa tidak tepat waktu. Dengan demikian, akan memperbaiki dan dapat meningkatkan akreditasi prodi untuk masa yang akan datang.

Sistem yang sedang berjalan dalam penentuan pembimbing skripsi dapat dikatakan cukup rumit. Mahasiswa mengajukan judul kepada pihak pengelola jurusan. Proses pengajuan oleh seorang mahasiswa dapat terjadi berulang kali hingga judulnya diterima dan ditentukan dosen pembimbing. Masalah pertama timbul karena penentuan dosen pembimbing dilakukan oleh jurusan, terkadang seorang dosen ditugaskan membimbing terlalu banyak mahasiswa sedangkan dosen yang lain hanya satu atau dua mahasiswa saja. Terkadang juga terdapat keputusan yang kurang optimal, karena kurang sesuai bidang keilmuan dosen dengan skripsi mahasiswa. Akibatnya dapat mengurangi kualitas tugas akhir yang dihasilkan, mahasiswa juga kurang optimal dalam hal penguasaan topik tersebut. Serta berbagai masalah lain yang harusnya tidak terjadi jika terdapat penataan segmentasi mahasiswa dan positioning dosen.

Penelitian mengenai Sistem Pengambilan Keputusan (SPK) dalam hal penentuan dosen pembimbing sudah banyak dilakukan. Yaqin et al. (2014) mengembangkan sebuah SPK penentuan dosen pembimbing menggunakan logika fuzzy. Penilaian ini berdasarkan bidang kompetensi dosen, ipk mahasiswa, beban bimbingan dosen, nilai skripsi mahasiswa yang telah menempuh sidang skripsi, durasi mahasiswa dalam menyelesaikan skripsi, serta kondisi khusus sebagai aspek pertimbangan (special case). Cahyono \& Thamrin (2016) membuat sebuah aplikasi penentu pembimbing skripsi menggunakan metode analytical hierarchy process (AHP), namun tingkat keakuratan aplikasi ini cukup lemah hanya 53.8\%. Di sisi lain, Septiana et al. (2016) mengembangkan SPK penentu dosen penguji dan pembimbing tugas akhir menggunakan Fuzzy Multiple Atribute Decision Making dengan Simple Addittive Weight (SAW). Laengge et al. (2016) juga mengembangkan sistem pendukung keputusan dalam menentukan dosen pembimbing menggunakan metode SAW. Pada 
penelitian tersebut sangat bergantung pada aspek variabel dan tingkat ketelitian perhitungan yang cukup rumit. Mukti et al. (2018) mengembangkan SPK dengan metode pembobotan TOPSIS, namun metode ini memiliki resiko kesalahan apabila bobot yang diberikan tidak sesuai. Selain itu, Putri (2019) mempelajari SPK untuk penentuan dosen pembimbing skripsi menggunakan algoritma Winnowing-Weighted Product dengan memperoleh hasil $90 \%$ tingkat usabilitas sistem dalam penentuan pembimbing skripsi. Tetapi pada penelitian tersebut, tidak dilakukan segmentasi mahasiswa, hanya terpaku pada reputasi akademik yang dimiliki dosen. Lebih lanjut, Pomantow et al. (2019) mengembangkan sistem segmentasi, targetting, dan positioning dalam hal penjualan suatu produk kopi. Penelitian tersebut bertujuan agar mengetahui gambaran produk oleh segmen pasar yang ada. Dalam bukunya Kotler (2008) menyatakan bahwa segmentasi pada dasarnya adalah suatu strategi untuk memahami struktur pasar. Sedangkan Kasali (1998) juga menyatakan salah satu metode statistika yang sering digunakan pada bidang ekonomi pemasaran adalag segmentasi dengan regresi.

Metode pada bidang ekonomi ini sangat mungkin untuk diterapkan pada kasus pemilihan pembimbing skripsi. Secara umum segmen mahasiswa dan positioning dosen akan dihitung secara bersamaan. Penelitian ini akan menggunakan analisis yang telah dikenalkan DeSarbo et al. (2008) yakni Clusterwise Bilinear Spatial Multidimensional Scaling Model (CBSMSM). Yanti et al. (2014) juga telah mengaplikasikan analisis ini pada ukuran data relatif kecil, namun kekonsistenan hasil belum maksimal karena hasil yang diperoleh sangat tergantung pada besarnya nilai dugaan awal variabelnya. Analisis CBSMSM ini akan dicoba diaplikasikan pada kasus penentuan pembimbing skripsi pada Jurusan IImu Komputer Universitas Pakuan. Pada metode ini dilakukan klasifikasi dan reduksi data secara bersamaan, sehingga prosesnya relatif lebih cepat dan menghasilkan efisiensi waktu maksimal. Dari penelitian Yanti et al.(2014) sebelumnya, penelitian ini menggunakan ukuran data yang lebih besar. Penggunaan algoritma alternating least square lebih stabil disertai dengan nilai akhir yang diperoleh tidak akan berubah walaupun penentuan nilai awal dugaan variabel bersifat acak. Diharapkan berdasarkan penelitian ini dapat menentukan gambaran segmentasi mahasiswa dan positioning dosen bersamaan pada suatu analisis yang secara langsung mempermudah penentuan dosen pembimbing skripsi berdasarkan segmen mahasiswanya. Akibatnya proses penyusunan skripsi dapat lebih maksimal dan memperkecil kemungkinan mahasiswa lulus tidak tepat waktu.

\section{Metodologi}

Penelitian ini dilakukan terhadap mahasiswa aktif semester V Jurusan Ilmu Komputer Universitas Pakuan pada Semester Genap TA 2019/2020. Jumlah responden sebanyak 200 mahasiswa yang ditanyakan penilaian terhadap 32 dosen aktif dengan 10 kategori atribut/ variabel. Selain itu, disertai satu pertanyaan konklusif penentuan besar keinginan mahasiswa ke- $i$ untuk bersedia dibimbing oleh dosen ke- $j$ yang nanti akan membentuk sebuah matriks $\left(\Delta_{i j}\right)$. Penilaian oleh seluruh responden terhadap dosen ke- $j$ berdasarkan atribut ke- $k$ akan membentuk matriks $\left(Z_{j k}\right)$.

Beberapa langkah penting yang dilakukan pada penelitian ini adalah sebagai berikut: 
1. Penentuan indikator kuesioner

Kuesioner yang digunakan terdiri dari 10 pertanyaan utama dan satu pertanyaan konklusif keinginan mahasiswa untuk dibimbing dosen ke-j yang mewakili tujuan penelitian. Indikator pertanyaan berdsarkan penelitian oleh Yanti et al. (2014). Kuesioner ini telah dilakukan pengujian validitas dan reliabilitas sebelumnya.

2. Pelaksanaan survei

Pengambilan data survei dilakukan secara langsung menggunakan media online. Hal ini dilakukan untuk mempermudah proses pelaksanaan survei, menekan biaya, dan lebih efisien terhadap waktu. Data survei penilaian responden ke- $i$ terhadap dosen ke- $j$ berdasarkan atribut ke- $k$ secara keseluruhan dapat disusun sesuai struktur data pada Tabel 1.

Tabel 1: Struktur data penilaian responden terhadap dosen dan atribut $\left(\boldsymbol{Z}_{\boldsymbol{j} \boldsymbol{k}}\right)$

\begin{tabular}{cccccc}
\hline Responden ke- $i$ & Dosen $(j)$ & Atribut ke-1 & Atribut ke-2 & $\ldots$ & Atribut ke- $K$ \\
\hline \multirow{4}{*}{1} & 1 & $Z_{11}$ & $Z_{12}$ & $\ldots$ & $Z_{1 K}$ \\
& 2 & $Z_{21}$ & $Z_{22}$ & $\ldots$ & $Z_{2 K}$ \\
$\vdots$ & $\vdots$ & $\vdots$ & $\vdots$ & $\ddots$ & $\vdots$ \\
& $J$ & $Z_{J 1}$ & $Z_{J 2}$ & $\ldots$ & $Z_{J K}$ \\
$N$ & $\vdots$ & $\vdots$ & $\vdots$ & $\ddots$ & $\vdots$ \\
& 1 & $Z_{11}$ & $Z_{12}$ & $\ldots$ & $Z_{1 K}$ \\
& 2 & $Z_{21}$ & $Z_{22}$ & $\ldots$ & $Z_{2 K}$ \\
& $\vdots$ & $\vdots$ & $\vdots$ & $\ddots$ & $\vdots$ \\
& $J$ & $Z_{J 1}$ & $Z_{J 2}$ & $\ldots$ & $Z_{J K}$ \\
\hline
\end{tabular}

Nilai $Z_{j k}$ yang diberikan oleh masing-masing responden secara garis besar dapat memberikan gambaran preferensi/ keinginan responden untuk memilih dosen tersebut. Namun dalam penelitian ini, untuk memperjelas besar keinginan mahasiswa dalam memilih dosen diberikan satu pertanyaan tersendiri. Besar keinginan responden ke- $i$ memilih dosen ke-j ditulis dengan matriks $\Delta_{i j}$ seperti pada Tabel 2.

Tabel 2: Struktur data keinginan responden ke- $\boldsymbol{i}$ untuk memilih dosen ke- $\boldsymbol{j}\left(\Delta_{i j}\right)$

\begin{tabular}{ccccc}
\hline Responden ke- $i$ & Dosen ke-1 & Dosen ke-2 & \multicolumn{2}{c}{ Dosen ke-J } \\
\hline 1 & $\Delta_{11}$ & $\Delta_{12}$ & $\ldots$ & $\Delta_{1 J}$ \\
2 & $\Delta_{21}$ & $\Delta_{22}$ & $\ldots$ & $\Delta_{2 J}$ \\
$\vdots$ & $\vdots$ & $\vdots$ & $\ddots$ & $\vdots$ \\
$\mathrm{N}$ & $\Delta_{N 1}$ & $\Delta_{N 2}$ & $\ldots$ & $\Delta_{N J}$ \\
\hline
\end{tabular}

3. Pemeriksaan terhadap data survei, karena sangat memungkinkan terdapat data kosong ataupun data tidak lengkap.

4. Deskripsi data survei yang telah dilaksanakan.

5. Pendugaan parameter

Yanti et al. (2014) mengaplikasikan CBSMSM menggunakan algoritma alternating least square. Matriks $X_{j r}$ menyatakan koordinat dosen ke-j untuk dimensi ke-r. Sedangkan besar pengaruh atribut ke- $k$ pada dimensi ke- $r$ untuk setiap dosen ke- $j$ diwakili oleh matriks $\alpha_{k r}$ dengan persamaan (1). Hubungan antara nilai atribut dengan keinginan memilih dosen oleh setiap responden pada segmen tertentu ditulis berdasarkan persamaan (2). 


$$
\begin{aligned}
X_{j r} & =\sum_{k=1}^{K} Z_{j k} \alpha_{k r} \\
\Delta_{i j} & =\sum_{r=1}^{R} X_{j r} Y_{s r}+\varepsilon_{i j}
\end{aligned}
$$

Persamaan (1) dan persamaan (2) ini bertujuan untuk positioning dosen, tidak dapat menggambarkan segmentasi dengan atribut. DeSarbo et al. (2008) memberikan ilustrasi simultan rumusan segmentasi dan positioning seperti pada persamaan (3). dengan $P_{i s}$ merupakan segmen yang keanggotaan peubah indikator biner, dengan syarat:

$P_{i s}=\left\{\begin{array}{l}0, \text { jika responden tidak dikelompokkan pada segmen } \mathrm{s} \\ 1, \text { jika responden dikelompokkan pada segmen s }\end{array}\right.$

Sehingga:

$P_{i s} \in\{0,1\}, \sum_{s=1}^{S} P_{i s}=1$, jika satu responden hanya masuk ke satu segmen saja;

$0<\sum_{s=1}^{S} P_{i s} \leq S$, jika satu responden masuk kedalam beberapa segmen; dan

$\Delta_{i j}=\sum_{s=1}^{S} P_{i s} \sum_{r=1}^{R} X_{j r} Y_{s r}+b+\varepsilon_{i j}$

Optimasi menggunakan algoritma alternating least square (DeSarbo, 2008) dapat dilakukan sebagai berikut. Persamaan (3) telah diperoleh: $\Delta_{i j}=$ $\sum_{s=1}^{S} P_{i s} \sum_{r=1}^{R} X_{j r} Y_{s r}+b+\varepsilon_{i j}$. Sehingga dapat diperoleh: $\varepsilon_{i j}=\Delta_{i j}-$ $\sum_{s=1}^{S} P_{i s} \sum_{r=1}^{R} X_{j r} Y_{s r}-b$. Untuk menduga $\boldsymbol{P}, \boldsymbol{X}, \boldsymbol{Y}$, dan $b$ dengan meminimumkan $\Phi$, dengan:

$\Phi=\sum_{\mathrm{i}=1}^{\mathrm{I}} \sum_{\mathrm{j}=1}^{\mathrm{J}}\left(\Delta_{\mathrm{ij}}-\sum_{\mathrm{s}=1}^{\mathrm{S}} \mathrm{P}_{\mathrm{is}} \sum_{\mathrm{r}=1}^{\mathrm{R}} \mathrm{X}_{\mathrm{jr}} \mathrm{Y}_{\mathrm{sr}}-\mathrm{b}\right)^{2}$

$\Phi=\sum_{\mathrm{i}=1}^{\mathrm{I}} \sum_{\mathrm{j}=1}^{\mathrm{J}} \varepsilon_{\mathrm{ij}}^{2}$

dengan $\Delta_{I J}=\left(\Delta_{i j}\right), \Delta_{i j}=\sum_{s=1}^{S} P_{i s} \sum_{r=1}^{R} X_{j r} Y_{s r}+b+\varepsilon_{i j}$, Misalkan $\Delta=\Delta^{*}+b$, maka $\Delta^{*}=\boldsymbol{P} \boldsymbol{Y} \boldsymbol{X}^{\prime}+\boldsymbol{\varepsilon}$, sehingga:

$\operatorname{Min} \Phi=\operatorname{Min} \operatorname{tr}\left(\boldsymbol{\varepsilon}^{\prime} \boldsymbol{\varepsilon}\right)=\operatorname{tr}\left[\left(\Delta^{*}-\boldsymbol{P} \boldsymbol{Y} \boldsymbol{X}^{\prime}\right)^{\prime}\left(\Delta^{*}-\boldsymbol{P} \boldsymbol{Y} \boldsymbol{X}^{\prime}\right)\right]=\operatorname{tr}\left(\Delta^{*} \Delta\right)-2 \operatorname{tr}\left(\Delta^{* \prime} \boldsymbol{P} \boldsymbol{Y} \boldsymbol{X}^{\prime}\right)+$ $\operatorname{tr}\left(\boldsymbol{X} \boldsymbol{Y}^{\prime} \boldsymbol{P}^{\prime} \boldsymbol{P} \boldsymbol{Y} \boldsymbol{X}\right)$

Berikut ini langkah dari algoritma alternating least square (ALS):

a) Menduga $\boldsymbol{X}$

Penduga nilai $\boldsymbol{X}$ menggunakan turunan parsial terhadap $\boldsymbol{X}$ dari JKG persamaan (4), sehingga diperoleh

$\widehat{\boldsymbol{X}}=\Delta^{* \prime} \boldsymbol{P} \boldsymbol{Y}\left(\boldsymbol{Y}^{\prime} \boldsymbol{P}^{\prime} \boldsymbol{P} \boldsymbol{Y}\right)^{-1}$

b) Menduga $Y$

Penduga nilai $\boldsymbol{Y}$ menggunakan turunan parsial terhadap $\boldsymbol{Y}$ dari JKG persamaan (4), sehingga diperoleh

$\widehat{\boldsymbol{Y}}^{\prime}=\left(\boldsymbol{X}^{\prime} \boldsymbol{X}\right)^{-1} \boldsymbol{X}^{\prime} \Delta^{* \prime} \boldsymbol{P}\left(\boldsymbol{P}^{\prime} \boldsymbol{P}\right)^{-1}$

c) Menduga $P$

Diketahui sebelumnya bahwa $P_{i s} \in\{0,1\}$ merupakan segmen keanggotaan peubah indikator biner, sehingga: $\sum_{s} P_{i s} \geq 1, \forall i$ dan $\sum_{s} P_{i s}>1, \forall S$, sehingga $\Phi=\operatorname{tr}\left(\boldsymbol{\varepsilon}^{\prime} \boldsymbol{\varepsilon}\right)=$ $\operatorname{tr}\left(\boldsymbol{\varepsilon}^{\prime} \boldsymbol{\varepsilon}\right)$ dan $\Phi=\sum_{i=1}^{I} H_{i i}$ dengan $\boldsymbol{H}=\boldsymbol{\varepsilon}^{\prime} \boldsymbol{\varepsilon}$ sehingga:

$\Phi=\sum_{i=1}^{I}\left(\Delta_{i}^{*}-P_{i} \boldsymbol{Y} \boldsymbol{X}^{\prime}\right)^{\prime}\left(\Delta_{i}^{*}-P_{i} \boldsymbol{Y} \boldsymbol{X}^{\prime}\right)$

d) Menduga $b$

Langkah pertama definisikan $\widehat{\Delta}_{i j}=\sum_{s=1}^{S} \hat{P}_{i s} \sum_{r=1}^{R} \widehat{X}_{j r} \widehat{Y}_{s r}$, dengan: $\boldsymbol{L}=\left(\Delta_{i j}\right), \quad \boldsymbol{K}=$ $(\mathbf{1}, \boldsymbol{M}), \mathbf{1}^{\prime}=(1,1, \cdots, 1), \boldsymbol{M}=\left(\hat{\Delta}_{i j}\right)$. Kemudian lakukan pendugaan kuadrat 
sederhana dengan persamaan (8). Dimana, nilai (a) ditetapkan sama dengan 1 karena tidak bisa diidentifikasi, karena berada pada $\boldsymbol{X}$ atau $\boldsymbol{Y}$

$$
\left(\begin{array}{l}
\hat{b} \\
\hat{a}
\end{array}\right)=\left(\boldsymbol{K}^{\prime} \boldsymbol{K}\right)^{-1} \boldsymbol{K}^{\prime} \boldsymbol{L}
$$

e) Uji konvergensi

Jika $V A F^{(I T)}-V A F^{(I T-1)} \leq 0.0001$ maka proses pendugaan akan berhenti, jika tidak, meningkatkan $I T=I T+1$ dan kembali ke Langkah 1. Nilai konvergensi (VAF) seperti halnya nilai $R^{2}$ menggunakan rumus

$$
V A F=1-\frac{\sum_{i=1}^{N} \Sigma_{j=1}^{J}\left(\Delta_{i j}-\widehat{\Delta}_{i j}\right)^{2}}{\sum_{i=1}^{N} \Sigma_{j=1}^{J}\left(\Delta_{i j}-\bar{\Delta}_{. .}\right)^{2}} \text {, dimana } \bar{\Delta}_{. .}=\frac{1}{N J} \sum_{i=1}^{N} \sum_{j=1}^{J} \Delta_{i j}
$$

6. Menentukan kombinasi banyak segmen dan dimensi untuk pendugaan parameter. Semakin banyak kombinasi yang dipilih, maka akan semakin banyak variasi yang akan dihasilkan. Namun ini berdampak kepada semakin lama proses penentuan kombinasi terbaik.

7. Memilih kombinasi banyak segmen dan dimensi. Kombinasi dikatakan terbaik jika memiliki jumlah Kuadrat Galat terkecil.

8. Hasil kombinasi terbaik kemudian disajikan pada suatu gambar dua dimensi yang berisikan koordinat segmen, koordinat dosen, koordinat atribut dan jumlah dimensi.

9. Menentukan kelompok dosen dan atribut untuk setiap segmen yang terbentuk dan kemudian dilakukan interpretasi hasil penelitian.

\section{Hasil dan Pembahasan}

\subsection{Deskripsi Data}

Berdasarkan perancangan awal, dilaksanakan survei terhadap 200 mahasiswa untuk penilaian terhadap 32 dosen dengan 10 atribut. Namun hanya terdapat 161 data responden yang memenuhi untuk dapat dianalisis. Skala atribut jawaban kuesioner ini terletak pada interval nilai 1-10, dengan 10 menyatakan sangat menyukai/ sangat setuju dan 1 menyatakan sebaliknya. Atribut yang digunakan adalah sebagai berikut:

A1 = Dosen mudah untuk ditemui

A2 = Track record bimbingan dosen tersebut cepat lulus

A3 = Dosen memiliki reputasi akademik yang baik

A4 = Dosen memiliki reputasi non akademik yang baik

A5 = Dosen dianggap lebih familiar oleh mahasiswa.

A6 = Terdapat komunikasi intens antara dosen dengan mahasiswa.

A7 = Dosen memiliki gaya mengajar yang unik

A8 = Dosen dirasa menakutkan oleh mahasiswa

A9 = Minat mahasiswa sesuai dengan bidang ilmu dosen

$\mathrm{A} 10=$ Dosen memiliki sifat kharismatik dan berkarakter

Sebaran rata-rata 10 atribut berdasarkan penilaian 161 mahasiswa terhadap 32 dosen disajikan pada Gambar 1. Pada gambar tersebut, dapat diketahui bahwa sifat kharismatik dan berkarakter bagi seorang dosen merupakan salah satu atribut yang paling diutamakan saat memilih dosen pembimbing skripsi. Secara keseluruhan, ratarata atribut berada pada rentang diatas 6 . 
Mahasiswa juga memberikan preferensi/ keinginan untuk memilih seorang dosen menjadi pembimbingnya yang secara deskriptif disajikan pada Gambar 2. Berdasarkan gambar tersebut dapat diperoleh informasi bahwa menurut penilaian mahasiswa, mereka sangat tidak mengharapkan untuk dibimbing oleh dosen 7 (D7), dosen (20) dan dosen 23 (D23). Serta yang menjadi dosen paling diharapkan oleh mahasiswa adalah dosen 20 (D20).

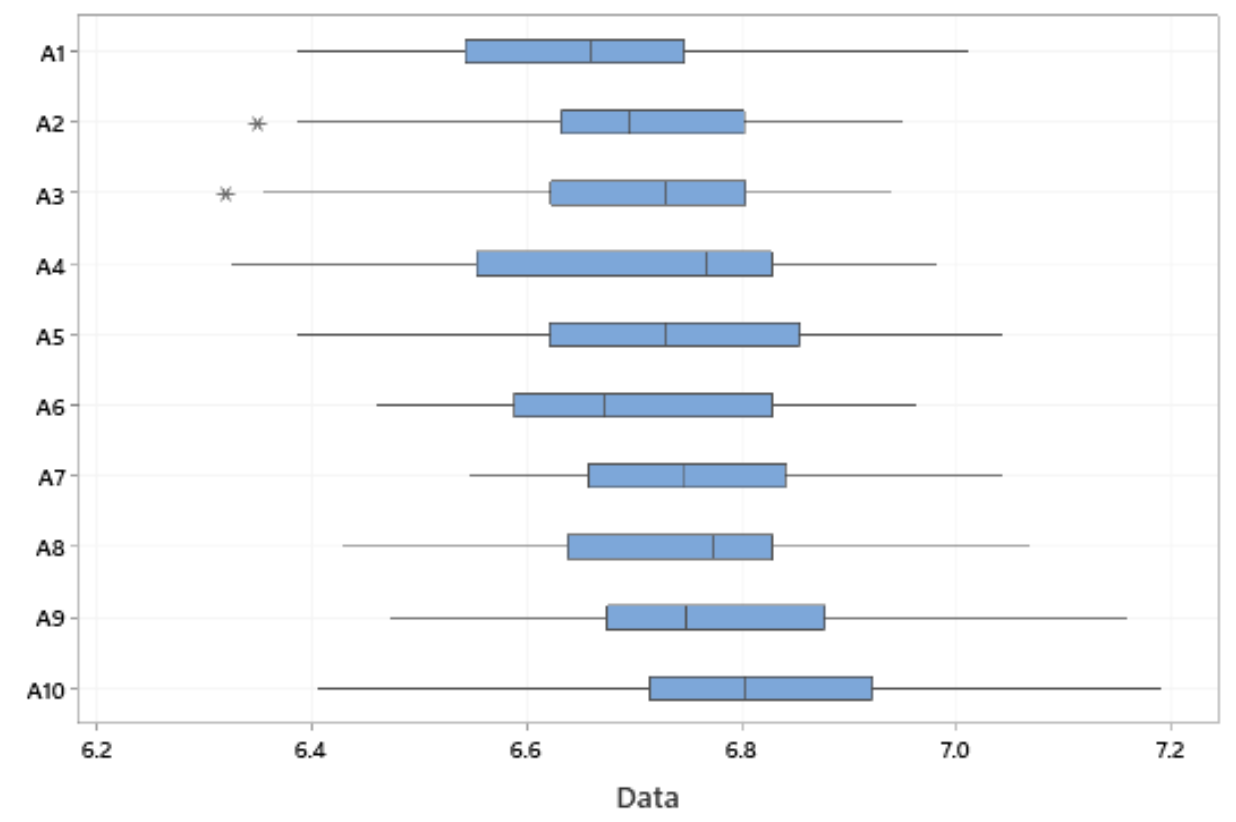

Gambar 1: Boxplot rata-rata penilaian mahasiswa untuk setiap atribut

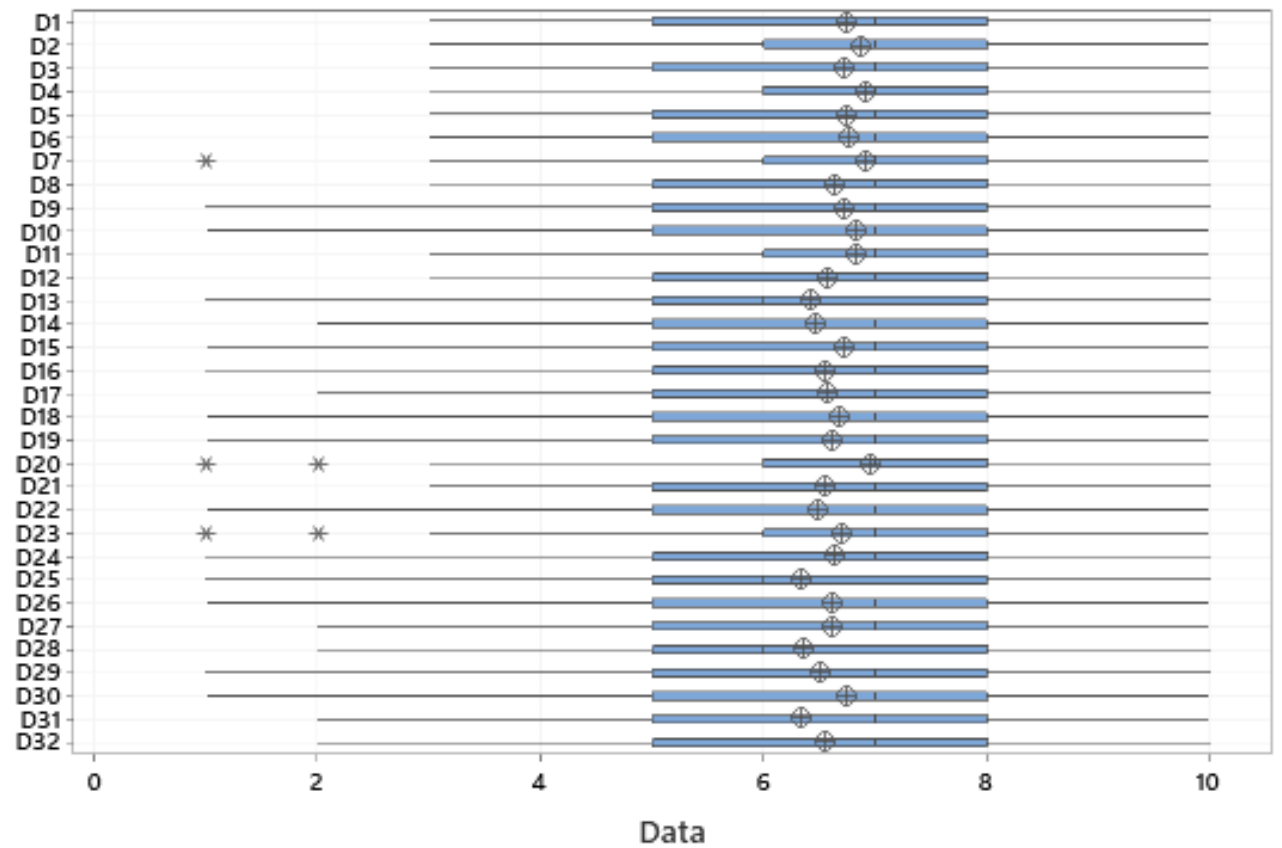

Gambar 2: Boxplot preferensi / keinginan mahasiswa dalam memilih dosen 


\subsection{Hasil}

Proses analisis diawali dengan pemeriksaan kelengkapan data survei. Awalnya kuesioner disebar kepada 200 mahasiswa, namun terdapat 39 kuesioner yang tidak memenuhi kriteria untuk diikutsertakan dalam analisis. Data yang ada dibentuk ke dalam struktur $\Delta$ dan $\boldsymbol{Z}$ yang kemudian disesuaikan dengan bahasa pemrograman $\mathrm{R}$, yang diikuti oleh inisialisasi nilai $\boldsymbol{P}$ dan $\boldsymbol{Y}$. Kemudian tahap yang tidak kalah penting yakni menentukan batas iterasi pendugaan parameter (er).

Selanjutnya dilakukan proses pendugaan menggunakan algoritma ALS. Langkah pertama melakukan pendugaan koordinat dosen $(\boldsymbol{X})$ dan pendugaan koordinat atribut. Langkah kedua menduga koordinat segmen $(\boldsymbol{Y})$. Kemudian untuk menentukan setiap mahasiswa menjadi pendukung pada suatu segmen dilakukan pendugaan $\boldsymbol{P}$ dan juga bergantung pada nilai $\boldsymbol{\Phi}$ untuk setiap mahasiswa. Nilai terendah akan mengidentifikasi mahasiswa masuk pada segmen tersebut. Mahasiswa diberikan nilai 1 untuk masuk segmen ini dan 0 untuk segmen lainnya. Langkah keempat, menduga nilai $\boldsymbol{b}$ yang diawali dengan menduga nilai $\Delta^{*}$ dan menduga $\Delta$. Kedua matriks ini dibentuk menjadi satu kolom yang nanti digunakan untuk menduga $\boldsymbol{b}$. Langkah kelima menghitung nilai VAF menggunakan persamaan (9). Model dikatakan baik jika $V A F_{i}-V A F_{i-1}<e r$, apabila terpenuhi maka iterasi akan berhenti. Setelah ini berdasarkan VAF ditentukan nilai JKG dari proses iterasi.

Kombinasi jumlah segmen dan jumlah dimensi dilakukan secara trial and error. Kombinasi dengan nilai JKG terkecil dintayakan sebagai kombinasi terbaik. Tabel 3 akan menyajikan beberapa kombinasi ini.

Tabel 3: Banyak iterasi, nilai JKG dan nilai VAF berdasarkan kombinasi banyak dimensi dan segmen

\begin{tabular}{ccrrc}
\hline Segmen $(\mathrm{S})$ & Dimensi (R) & Iterasi & JKG & VAF \\
\hline 2 & 2 & 15 & 5096.160 & 0.010838500 \\
3 & 2 & 242 & 5052.924 & 0.019230550 \\
4 & 2 & 10 & 5053.737 & 0.019072860 \\
5 & 2 & 41 & 5123.098 & 0.005609905 \\
3 & 3 & 34 & 5106.183 & 0.008893057 \\
4 & 3 & 38 & 5063.909 & 0.017098360 \\
5 & 3 & 234 & 4980.604 & 0.033267930 \\
$4^{*}$ & $4^{*}$ & 24 & 4864.003 & 0.055900070 \\
5 & 4 & 106 & 5135.355 & 0.003230694 \\
5 & 5 & 136 & 4895.180 & 0.049848510
\end{tabular}

Keterangan: tanda * menyatakan kombinasi banyak dimensi dan segmen dengan JKG terkecil

Berdasarkan Tabel 3 di atas, terlihat bahwa kombinasi antara 4 segmen dan 4 dimensi memiliki JKG terkecil senilai 4864.003 dengan membutuhkan sebanyak 24 iterasi. Selanjutnya hasil analisis diilustrasikan dalam bentuk gambar. Penyajiannya dalam bentuk koordinat dua dimensi berupa Gambar 3 yang menyajikan hasil untuk dimensi 1 dan dimensi 2, serta Gambar 4 untuk dimensi 3 dan dimensi 4 . Tujuan dari membagi penyajian pada dua dimensi gambar ini agar mempermudah penyajian dan interpretasi hasil. 


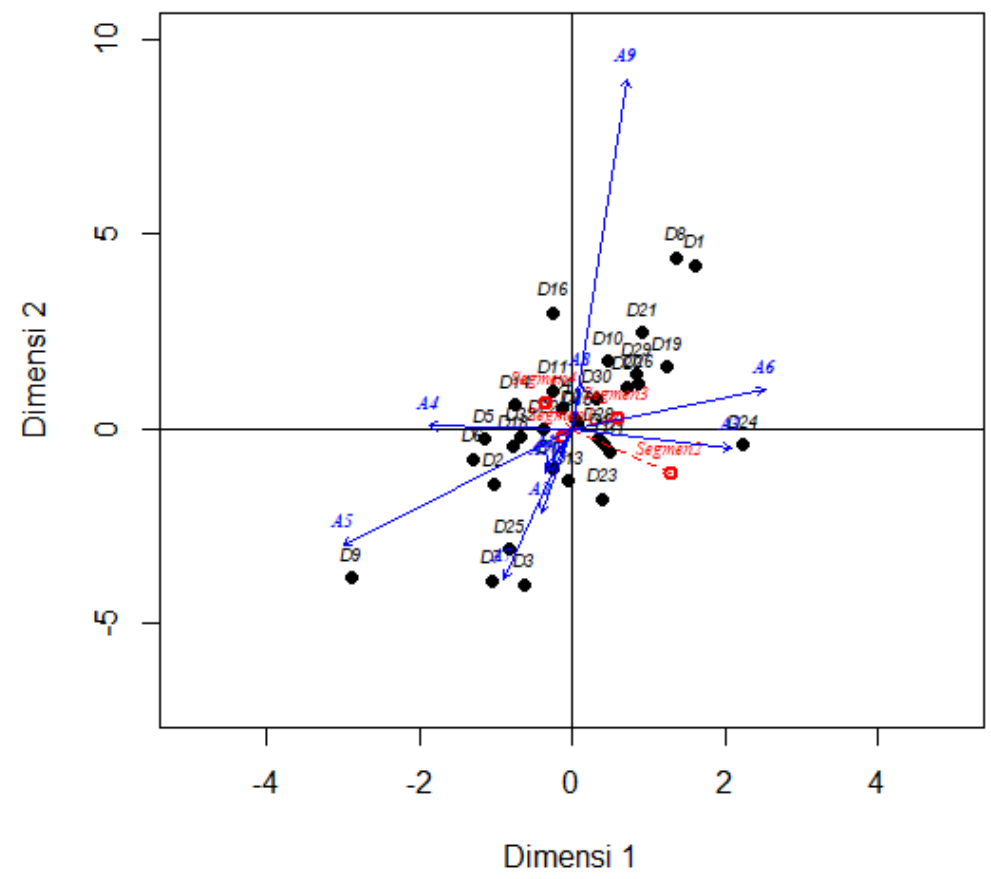

Gambar 3: Solusi analisis pada dimensi 1 dan dimensi 2

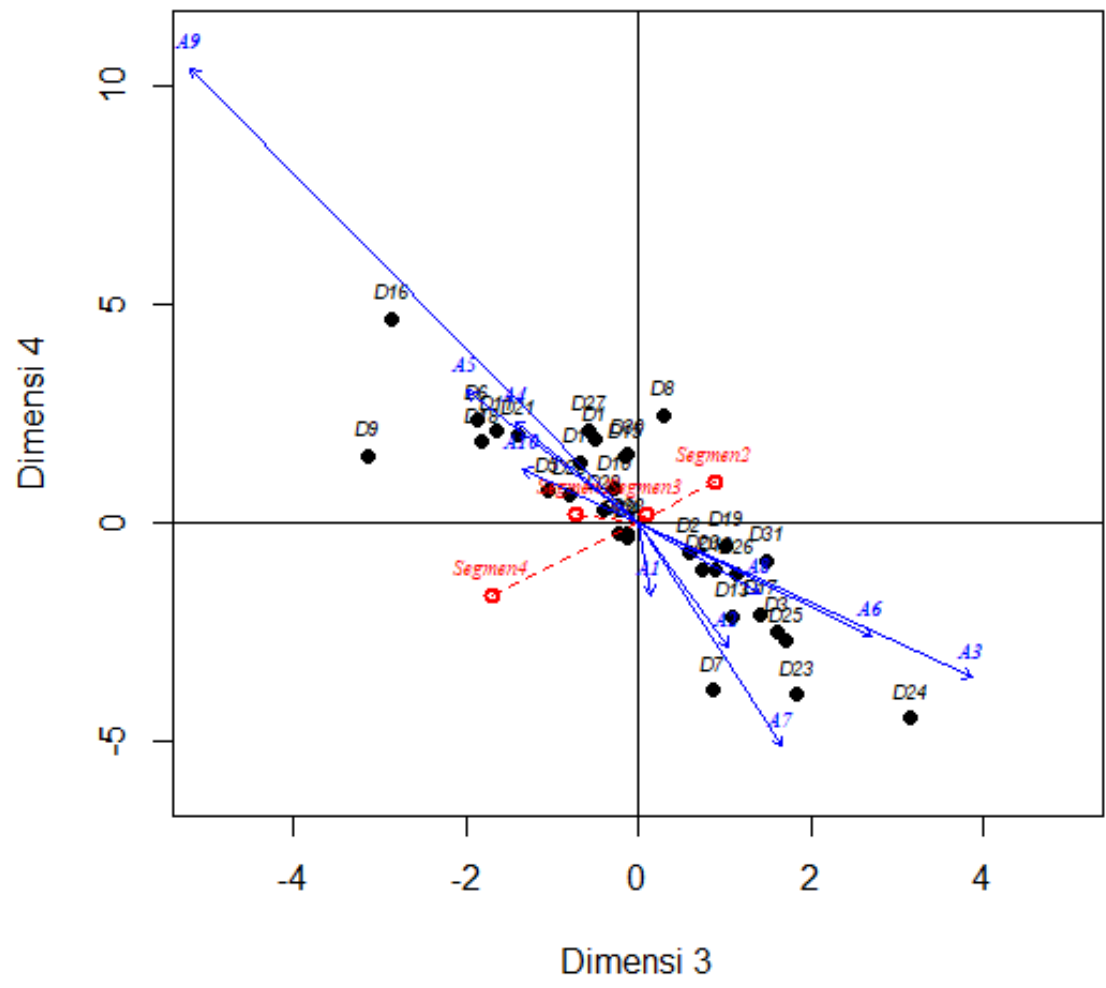

Gambar 4: Solusi analisis pada dimensi 3 dan dimensi 4 
Garis biru pada gambar mewakili atribut, garis merah putus-putus mewakili segmen dan titik hitam menunjukkan positioning dosen. Berdasarkan Gambar 3 terlihat bahwa segmen menyebar dengan baik, yang mengindikasikan bahwa setiap segmen berbeda dengan segmen lainnya. Suatu atribut dapat menggambarkan suatu segmen jika nilai proyeksi atribut terhadap segmen tersebut lebih besar dari rata-rata tersebut ditambah setengah simpangan bakunya. Sehingga terdapat kemungkinan atribut yang sama dapat menggambarkan lebih dari satu segmen. Kemudian, atribut dosen memiliki reputasi akademik yang baik (A3) menjadi pembentuk S2 dan S3. Terdapat komunikasi intens antara dosen dan mahasiswa (A6) juga menjadi pembentuk dua segmen yakni S2 dan S3. Atribut dosen dirasa menakutkan oleh mahasiswa (A8) dapat dilihat menjadi pembangun S3 dan S4. Dosen memiliki sifat kharismatik dan berkarakter (A10) menjadi pembangun S1 dan S2. Untuk lebih jelas akan disajikan pada Tabel 4.

Tabel 4: Proyeksi setiap atribut terhadap segmen

\begin{tabular}{lrrrr}
\hline \multirow{2}{*}{ Atribut } & \multicolumn{4}{c}{ Segmen } \\
\cline { 2 - 5 } & \multicolumn{1}{c}{ S1 } & \multicolumn{1}{c}{ S2 } & S3 & \multicolumn{1}{c}{ S4 } \\
\hline A1= Dosen mudah untuk ditemui. & -1.4901 & -0.8673 & -8.4075 & 1.6511 \\
A2= Track record bimbingan dosen tersebut cepat lulus & -3.2720 & 0.1266 & -7.3488 & 0.7022 \\
A3= Dosen memiliki reputasi akademik yang baik & -10.2270 & 1.3176 & 2.7327 & -0.5111 \\
A4= Dosen memiliki reputasi non akademik yang baik. & 8.2956 & -1.0540 & -4.7374 & -0.3509 \\
A5= Dosen dianggap lebih familiar oleh mahasiswa. & 8.8670 & 0.2224 & -8.0881 & -0.7436 \\
A6= Terdapat komunikasi intens antara dosen dengan & -10.3877 & 1.0069 & 6.7496 & -0.1917 \\
$\quad$ mahasiswa. & -2.9204 & -0.0158 & -7.7214 & 0.8182 \\
A7= Dosen memiliki gaya mengajar unik & -10.5278 & -1.2360 & 1.6508 & 0.6528 \\
A8= Dosen dirasa menakutkan oleh mahasiswa. & 3.9745 & -0.6212 & 6.3917 & -0.2961 \\
A9= Minat mahasiswa sesuai dengan bidang ilmu & & & \\
dosen. & 11.0477 & 0.7833 & -3.6671 & -0.2925 \\
A10= Dosen memiliki sifat kharismatik dan berkarakter .
\end{tabular}

Keterangan: pewarnaan kuning menandakan nilai proyeksi yang lebih besar dari rata-ratanya ditambah setengah simpangan bakunya pada setiap atribut

Segmen 1 (S1) digambarkan oleh atribut dosen memiliki reputasi non akademik yang baik (A4), dosen dianggap lebih familiar oleh mahasiswa (A5), minat mahasiswa sesuai dengan bidang ilmu dosen (A9) dan dosen memiliki sifat kharismatik dan berkarakter (A10). Untuk S2 digambarkan oleh atribut dosen memiliki reputasi akademik yang baik (A3), terdapat komunikasi intens antara dosen dengan mahasiswa (A6), dosen memiliki sifat kharismatik dan berkarakter (A10). Segmen 3 (S3) terbentuk oleh atribut dosen memiliki reputasi akademik yang baik (A3), terdapat komunikasi intens antara dosen dengan mahasiswa (A6), dosen dirasa menakutkan bagi mahasiswa (A8), minat mahasiswa sesuai dengan bidang ilmu dosen (A9). Segmen 4 terbentuk oleh atribut dosen mudah untuk (A1), track record bimbingan dosen tersebut cepat lulus (A2), dosen memiliki gaya mengajar unik (A7) dan dosen dirasa menakutkan mahasiswa (A8). 
Setiap dosen dapat diposisikan pada suatu segmen jika proyeksi dosen terhadap segmen tersebut memiliki nilai terbesar dari proyeksi terhadap segmen yang lain. Pada penelitian ini terdapat 32 orang dosen yang akan diposisikan pada 4 segmen. Posisi dosen terhadap segmen dapat dilihat secara detail pada Tabel 5.

Tabel 5: Proyeksi dosen terhadap segmen

\begin{tabular}{lrrrr}
\hline & \multicolumn{4}{c}{ Segmen } \\
\cline { 2 - 5 } Dosen & \multicolumn{1}{c}{ S1 } & \multicolumn{1}{c}{ S } & \multicolumn{1}{c}{ S4 } \\
\hline D1 & -6.6128 & -2.9329 & 50.8042 & -0.0865 \\
D2 & -1.4650 & 0.4180 & -22.2599 & -0.7566 \\
D3 & -10.5014 & 6.2321 & -37.8540 & -1.7068 \\
D4 & -1.2158 & -2.5154 & -0.3269 & 1.8231 \\
\hline D5 & 17.6062 & -3.0949 & -14.8273 & 1.2868 \\
D6 & 34.4706 & -0.5163 & -14.2913 & -1.3244 \\
D7 & -5.6887 & 0.6461 & -49.8150 & 4.2816 \\
D8 & -13.9827 & -1.4664 & 52.6203 & -3.3823 \\
D9 & 60.6513 & -1.5653 & -57.0565 & 2.0008 \\
D10 & -1.5107 & -1.9245 & 18.2739 & 0.3052 \\
D11 & 22.5968 & -1.9838 & 8.3176 & 0.0226 \\
D12 & -9.1582 & 1.4057 & -12.0103 & -0.4954 \\
D13 & -14.2766 & 0.9340 & -15.5221 & 1.3178 \\
D14 & 11.6278 & -2.1173 & -1.3875 & -0.7340 \\
D15 & 5.8418 & 2.6704 & 7.8975 & -3.5147 \\
D16 & 37.3102 & -4.1542 & 27.7875 & -1.3078 \\
D17 & -22.3522 & 0.6813 & -3.2070 & 1.0608 \\
D18 & 29.8223 & -0.8736 & -7.6988 & 0.0288 \\
D19 & -21.6789 & 0.5061 & 24.0651 & -0.3948 \\
D20 & -17.2793 & -1.2774 & 11.8147 & 1.5212 \\
D21 & 11.7165 & -2.1011 & 30.9959 & 0.5387 \\
D22 & 2.8488 & -1.9778 & -6.5862 & 1.5117 \\
D23 & -27.8550 & 1.1409 & -18.7041 & 3.3193 \\
D24 & -53.4550 & 4.3826 & 12.4068 & 1.6026 \\
D25 & -15.1022 & 3.1839 & -36.1286 & -0.3164 \\
D26 & -22.5280 & -0.5619 & 14.4270 & 0.7575 \\
D27 & 12.5574 & 2.7663 & 9.5805 & -3.8418 \\
D28 & 11.4493 & 1.3728 & 3.9903 & 0.0122 \\
D29 & -1.4039 & -1.2429 & 18.9499 & 1.3016 \\
D30 & 3.1145 & 2.0246 & 14.6892 & -3.2720 \\
D31 & -18.5482 & 4.0106 & 2.0364 & -2.6773 \\
D32 & 3.0012 & -2.0698 & -10.9812 & 1.1186 \\
\hline
\end{tabular}

Keterangan: pewarnaan kuning menandakan nilai proyeksi terbesar pada setiap segmen untuk masingmasing dosen

Berdasarkan Tabel 5, pada segmen 1 terdapat 11 dosen di dalamnya, yaitu dosen $5,6,9,11,14,16,18,22,27,28$, dan 32. Pada segmen 2 terdiri dari 5 dosen meliputi 
dosen 2, 3, 12, 25, dan 31. Pada segmen 4 juga terdapat 5 dosen, yaitu dosen 4, 7 , 13, 17, dan 3. Selainnya, termasuk pada segmen 3. Secara keseluruhan dapat digambarkan segmentasi mahasiswa beserta positioning-nya pada semua segmen pada tabel 6 .

Tabel 6: Ringkasan hasil analisis segmentasi mahasiswa dan positioning dosen

\begin{tabular}{|c|c|c|}
\hline Segmen & Atribut pembangun segmen & $\begin{array}{l}\text { Dosen yang memenuhi kriteria } \\
\text { segmen }\end{array}$ \\
\hline Segmen 1 & $\begin{array}{l}\mathrm{A} 4=\text { Dosen memiliki reputasi non akademik } \\
\text { yang baik } \\
\mathrm{A} 5=\text { Dosen dianggap lebih familiar oleh } \\
\text { mahasiswa.. } \\
\mathrm{A} 9=\text { Minat mahasiswa sesuai dengan bidang } \\
\text { ilmu dosen. } \\
\mathrm{A} 10=\text { Dosen memiliki sifat kharismatik dan } \\
\text { berkarakter. }\end{array}$ & $\begin{array}{l}\text { Dosen 05, Dosen 06, Dosen 09, } \\
\text { Dosen 11, Dosen 14, Dosen 16, } \\
\text { Dosen 18, Dosen 22, Dosen 27, } \\
\text { Dosen 28, Dosen } 32\end{array}$ \\
\hline Segmen 2 & 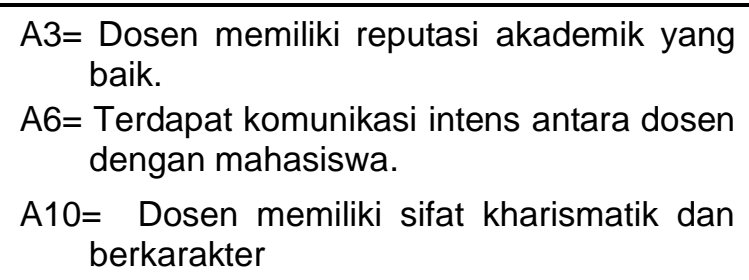 & $\begin{array}{l}\text { Dosen 02, Dosen 03, Dosen 12, } \\
\text { Dosen 25, Dosen } 31\end{array}$ \\
\hline Segmen 3 & $\begin{array}{l}\mathrm{A} 3=\text { Dosen memiliki reputasi akademik yang } \\
\text { baik. } \\
\mathrm{A} 6=\text { Terdapat komunikasi intens antara dosen } \\
\text { dengan mahasiswa. } \\
\mathrm{A} 8=\begin{array}{c}\text { Dosen dirasa menakutkan oleh } \\
\text { mahasiswa. }\end{array} \\
\mathrm{A} 9=\begin{array}{l}\text { Minat mahasiswa sesuai dengan bidang } \\
\text { ilmu dosen. }\end{array}\end{array}$ & $\begin{array}{l}\text { Dosen 01, Dosen 08, Dosen 10, } \\
\text { Dosen 15, Dosen 19, Dosen 20, } \\
\text { Dosen 21, Dosen 24, Dosen 26, } \\
\text { Dosen 29, Dosen } 30\end{array}$ \\
\hline Segmen 4 & $\begin{array}{l}\mathrm{A} 1=\text { Dosen mudah untuk ditemui. } \\
\mathrm{A} 2=\text { Track record bimbingan dosen tersebut } \\
\text { cepat lulus. } \\
\mathrm{A} 7=\text { Dosen memiliki gaya mengajar yang unik. } \\
\mathrm{A} 8=\begin{array}{c}\text { Dosen dirasa menakutkan oleh } \\
\text { mahasiswa. }\end{array}\end{array}$ & $\begin{array}{l}\text { Dosen 04, Dosen 07, Dosen 13, } \\
\text { Dosen 17, Dosen } 23\end{array}$ \\
\hline
\end{tabular}

\section{Simpulan}

Berdarkan analisis yang telah dilakukan maka dapat disimpulkan bahwa terdapat 4 segmen mahasiswa pada Jurusan IImu Komputer Universitas Pakuan. Positioning dosen hanya pada satu segmen untuk setiap dosen, sedangkan atribut memungkinkan untuk menjadi bagian untuk lebih dari satu segmen. Mahasiswa pada segmen 1 lebih cenderung memilih dosen pembimbing dengan reputasi non akademik yang lebih menonjol, dosen yang lebih familiar dengan sifat kharismatik dan tentunya sesuai dengan bidang ilmu yang diminati. Pada segmen 2 diisi oleh mahasiswa yang lebih sering berinteraksi dengan dosen yang memiliki sifat kharismatik serta reputasi akademik yang lebih baik. Mahasiswa pada segmen 3 hampir menyerupai kriteria pada segmen 2, namun pada segmen 3 ini mahasiswa lebih memilih dosen dengan kesan lebih menakutkan untuk membimbing skripsinya. Terakhir untuk segmen 4 , 
mahasiswa pada segmen ini lebih mengutamakan rasa kemudahan untuk bertemu dosen, walaupun kesan dosen lebih menakutkan, namun dosen pada segmen ini memiliki track record bimbingan cepat lulus.

\section{Daftar Pustaka}

Cahyono, H. A., \& Thamrin, H. (2016). Sistem Pendukung Keputusan Penentuan Pembimbing Skripsi Menggunakan Metode Analytical Hierarchy Process. Retrieved March 25, 2021, from http://eprints.ums.ac.id/41390/1/Naskah_Publikasi_Hendri_L200110090.pdf

DeSarbo, W. S., Grewal, R., \& Scott, C. J. (2008). A Clusterwise Bilinear Multidimensional Scaling Methodology for Simultaneous Segmentation and Positioning Analysis. Journal of Marketing Research, 45(3): 280-292.

Kasali, R. (1998). Membidik Pasar Indonesia Segmentasi Targeting Positioning. Jakarta (ID): Gramedia.

Kotler, P. (2008). Manajemen Pemasaran. Jakarta (ID): Erlangga.

Laengge, I., Wowor, H. F., \& Putro, M. D. (2016). Sistem Pendukung Keputusan dalam Menentukan Dosen Pembimbing Skripsi. Jurnal Teknik Informatika, 9(1): 1-7.

Mukti, T. H., Patmantara, S., \& Wibawa, A. P. (2018). Sistem Pemilihan Dosen Pembimbing Skripsi dengan Metode Topsis. Jurnal IImiah Flash, 4(1): 53-63.

Pomantow, G. V., Mananeke, L., \& Jorie, R. J. (2019). Analisis Segmentasi, Targeting, Dan Positioning Terhadap Keputusan Pembelian Produk Maxx Coffee Di Hotel Aryaduta Manado. Jurnal Emba: Jurnal Riset Ekonomi, Manajemen, Bisnis Dan Akuntansi, 7(4): 3129-3138.

Putri, R. A. N. (2019). Sistem Pendukung Keputusan untuk Penentuan Dosen Pembimbing Skripsi menggunakan Algoritme Winnowing-Weighted Product. Jurnal Pengembangan Teknologi Informasi Dan IImu Komputer, 3(9): 91329138.

Septiana, I., Irfan, M., Atmadja, A. R., \& Subaeki, B. (2016). Sistem Pendukung Keputusan Penentu Dosen Penguji dan Pembimbing Tugas Akhir Menggunakan Fuzzy Multiple Attribute Decision Making Dengan Simple Additive Weighting. JOIN, 1(1): 43-50.

Yanti, Y., Sartono, B., \& Afendi, F. M. (2014). Simultaneous Analysis Of The Lecturers Positioning And Students Segmentation In The Selection Of Thesis Supervisor. Proc. ICCS-13, 311-318. Bogor (ID): Departemen Statistika, FMIPA, IPB.

Yaqin, A., Utami, E., \& Luthfi, E. T. (2014). Sistem Pendukung Keputusan Dosen Pembimbing dengan Metode Logika Fuzzy. Prosiding Seminar Informatika 2014, 146-159. Medan (ID): STMIK Potensi Utama. 